\title{
Saved by the civil war: African 'loyalists' in the Portuguese armed forces and Angola's transition to independence
}

\author{
Pedro Aires Oliveira \\ Instituto de História Contemporânea, Faculdade de Ciências Sociais e \\ Humanas, Universidade Nova de Lisboa, 1069-061 Lisboa \\ mpoliveira@fcsh.unl.pt
}

\begin{abstract}
The article examines the trajectories of 'loyal' African troops in Angola before and after the demise of Portugal's authoritarian regime in 1974. It starts by placing the 'Africanization' drive of the Portuguese counterinsurgency campaign in a historical perspective; it then explores the rocky transition from colonial rule to independence in the territory between April 1974 and November 1975, describing the course of action taken by the Portuguese authorities vis-à-vis their former collaborators in the security forces. A concluding section draws a comparison between the fate of Portugal's loyalists in Angola and the one experienced by similar groups in other ex-Portuguese colonies. The choice of Angola has the advantage of allowing us to look into a complex scenario in which the competition amongst rival nationalist groups, and a number of external factors, helped to produce a more ambiguous outcome for some of the empire's local collaborators than what might have been otherwise expected.
\end{abstract}

Keywords: Angola; colonial troops; Loyalists; counter-insurgency; Decolonization

The dissolution of Portugal's overseas empire in 1975 happened after a protracted counterinsurgency war which took place in three of its African territories (Angola, Guinea-Bissau and Mozambique), a 13 year conflict (196174) that put an enormous strain on the limited demographic and economic resources of what was then Western Europe's poorest and most undeveloped 
state. The gradual weariness produced by the stalemate in Africa did not bring about a significant change in the discourse articulated by Portugal's last authoritarian leader, Marcelo Caetano. Until his demise, in April 1974, Caetano remained hostage to the basic tenets of the hard-line stance on the empire, which stressed the 'intangibility' of the nation's colonial sovereignty and refused to contemplate even an 'evolution' towards a more decentralized-cum federalized imperial structure (as Caetano himself had proposed in the early 1960s). For the most intransigent elements of the regime, the notion of a negotiation with the African guerrillas was conceived as a betrayal of the nation's 'sacred heritage', as well as a threat to the country's own security and economic independence. ${ }^{1}$

During his six-year tenure, Caetano strengthened Portugal's ties with the white powers of southern Africa and tried to suppress (or at least contain) the insurgents' challenge. The most he was prepared to concede was a measure of administrative autonomy to the overseas provinces, while hoping that the pace of economic growth would diminish the appeal of the nationalists in Angola and Mozambique. Until 1971, at least, there was even hope in Lisbon that a 'decisive' military victory might be achieved. Charismatic generals in Angola, Guinea and Mozambique were given carte blanche to conduct bold operations against the guerrilla's bases and sanctuaries, some of them involving the violation of the territorial sovereignty of neighbouring states, and efforts were undertaken to acquire military equipment best suited to a counterinsurgency conflict, such as helicopters and light aircraft. Ambitious resettlements schemes were implemented with a view to isolate the noncombatant civilian populations from the guerrillas, while sums allocated in the Development Plans to the welfare of the Africans were reinforced. ${ }^{2}$

Aware of the war's growing unpopularity, especially among young male adults and their families, Caetano was anxious to find ways of alleviating the war's burden in the metropolis. This meant two things. One was to increase the financial contribution of the two larger provinces, Angola and Mozambique, to meet their own administration and 'security' costs. The other, which will be examined in this article, was the expansion of the military conscription in the 
overseas territories and the deployment of an ever-growing number of 'auxiliary' or 'irregular' native troops. This latter option was also expected to add credibility to an important feature of the regime's propaganda - the claim that Portugal was not fighting a war to prop up the privileges of a white minority, or selfish metropolitan interests, but rather to help Guineans, Angolans and Mozambicans defend themselves against the 'foreign aggression' of guerrillas trained and armed by communist powers. Even though a hypothetical future political role for those African 'loyalists' who rallied to the Portuguese flag was never openly discussed, they would gradually come to constitute an important element of Portugal's security apparatus in the final days of empire.

\section{War on the cheap: Portugal and its collaborators in Angola}

The enlistment of African elements either as allies or auxiliaries as part of Portugal's drive to expand and consolidate its influence in Angola had a long historical pedigree, going back to the early $17^{\text {th }}$ century. The number of Africans involved in such campaigns, however, only acquired major significance from the mid- $19^{\text {th }}$ century, when Portugal sought to establish a regular presence in the hinterland of Angola. 3 The colonial army accommodated Africans (many of them of mulattoes or 'assimilated' blacks) predominantly as 'second line forces', sometimes recruited in native regulados, and usually organized in mobile companies led by loyal African chiefs or white settlers. 4 But the Portuguese also called upon the service of African native armies, better known as empacaceiros (hunters of wild buffaloes) or guerra preta (literally 'black war'), who were rewarded with a share of the spoils of war. Without such assistance, Portugal could not have extended its hegemony into the hinterlands of its African colonies. African colonial military units, whose soldiers were commonly known as cipaios, also proved their usefulness by being deployed to other parts of the Portuguese empire - whether to deal with 'emergencies', or simply to garrison distant imperial outposts at Goa, Macau and East Timor. 5

While a few Africans of mixed ethnic origins were able to achieve high rank in the imperial army by the mid-nineteenth century, ${ }^{6}$ the diffusion of Social-Darwinist prejudices in the last decades of the century led to a complete 
'whitening' of the 'first line forces', which then comprised of only expeditionary elements sent from Lisbon. Creole or mulatto Angolans, who had profited from their status as intermediaries in previous stages of the colony's history, were now regarded with suspicion, and sometimes scorn, by the Portuguese authorities, and deemed unfit for command responsibilities.7 To keep military costs down, however, reforms were introduced in 1901 to meet the security needs of colonial territories by raising local companies, some of mixed origin, others solely constituted by black soldiers, but always headed by European officers and sergeants ${ }^{8}$. Although termed 'voluntary', such companies were in fact raised through the use of coercive methods ("round-ups"), which might involve the taking of hostages and the threat of retaliations against entire villages, very much in line with other requisitioning procedures for public sector works, mines and plantations then common in Angola.9

Harsh indigenato codes, such as the one adopted in 1899, allowed for the forced incorporation of Africans as cipaios and porters in great numbers. This was used during the early stages of the Great War, when southern Angola came under threat from the neighbouring Germans, and then in the critical phase of the 'pacification campaigns' of 1916-21. In 1926, further legislation was introduced to secure more systematic recruitment for the colonial army, making the enlistment of 'indigenous' soldiers compulsory. Governors were instructed to determine the annual contingent of African recruits, taking into account the security situation of the territory and the needs of its labour-intensive economy. Race inevitably determined the status of such recruits. Africans were rarely promoted beyond the rank of corporal, received uniforms of a lower quality, and received lower pay than their European counterparts. ${ }^{10}$ While financial considerations provided the basic rationale for the 1926 reform, concerns with the 'nationalization' of Portugal's African subjects were also relevant. Service in the colonial army was viewed as a way to ensure the 'ablest' elements of the native population were given elementary instruction in Portuguese language and literacy, and infused with a patriotic spirit that would build allegiance towards the Portuguese flag and national anthem. ${ }^{11}$ In the 1930s, when crude racism became commonplace in the speeches of Portuguese officials, an 
exception was usually made to the 'noble warrior races' that had proven their value by joining the military cadres that defended the colonies. ${ }^{12}$

This framework remained in place until the outbreak of the colonial wars in 1961. As nationalism began to emerge elsewhere in Africa during the 1950s, Portugal's leaders failed to appreciate the challenge that might soon face them. In 1954, a new 'Statute of the Indigenous' reaffirmed the basic tenets of the old indigenato system. The colonial army's racial hierarchies were kept in place, with soldiers now being recognised in one three categories: 'commissioned' (reserved for whites from the metropolis or the overseas provinces); 'overseas' (Africans recognized as assimilados); and 'natives' (Africans recognized as 'non-assimilated').13 By 1960, on the eve of the nationalist insurrection, the 'overseas' and 'native' contingents in Angola numbered 5,000, while there were only 1,500 commissioned white soldiers. ${ }^{14}$

As the nationalist uprisings commenced in the early months of 1961 , the government responded by introducing a range of legal measures designed to strengthen their assimilationist and 'colour-blind' policy. In November, the indigenato system was repealed, this action theoretically at least placing all colonial inhabitants of the Ultramar (Overseas, the new label for the empire introduced by the regime in 1951) on the same footing with metropolitan citizens. For the army, this should have led directly to the abolition of the racial hierarchies restricting rank and status: But, as in other spheres of Portuguese colonial society, racial forms of discrimination persisted. Formal educational skills, and knowledge of the Portuguese language now became requirements determining rank in the military, this effectively restricting African advancement. 15

During the early stages of the war in Angola the fighting was largely conducted by a metropolitan conscript force, the numbers of which soon exceeded those of the locally recruited Africans. From just 1,500 soldiers in 1960, the number of expeditionary elements swelled to 28,477 in 1961 (84.1\% of the total recruitment) and then to $34,530(72 \%)$ in 1963 , and $38,564(69 \%)$ in $1966 .{ }^{16}$ The laws regulating the conscription service in the Ultramar were the 
same as in the metropolis (all able bodied men aged between 20 and 45 five were liable to serve in the military), but, as Cann notes, ${ }^{17}$ in the colonies this legislation was enforced less strictly in the initial years of the insurgency perhaps on account of the fears in the minds of many Europeans in wake of the racial violence that had engulfed Angola in the Luanda riots of February 1961, and the UPA (União das Populações de Angola) rising in the following month. ${ }^{18}$

However, by 1966, with insurgencies in Guinea (since 1963) and Mozambique (1964), Portuguese military planners were beginning to struggle to meet the manpower demands posed by colonial wars. Portugal's male youth pool was being drained by the high levels of legal as well as clandestine migration to Western European countries. Due to the unpopularity of the colonial wars among the small but socially influent student population in the metropolis, the number of draft dodgers and deserters was increasing. There was also a significant decline in the number of applications to the national Military Academy. To address these problems, the government decided in 1968 to shift the focus of recruitment from the metropole to the colonies, intensifying conscription in the overseas territories and creating special paramilitary units drawn from the African population. ${ }^{19}$ The overall impact of this 'Africanization' drive in Angola remains difficult to assess. There is very little hard data on those non-white Africans who enrolled in the regular army, since Portuguese official statistics ceased to record ethnicity following the repeal of the indigenato system in 1961. Of the 228,842 locally recruited soldiers in Angola between 1961 and 1974, ${ }^{20}$ demographics suggest that a high percentage were either mulattos or blacks. ${ }^{21}$ These soldiers were usually integrated into ethnically 'mixed' companies, received the same pay as their European counterparts, and, theoretically at least, had no impediments to promotion. Despite this apparently 'inclusive' approach, few black soldiers made it to the rank of captain, and none managed to rise higher. ${ }^{22}$

The separation of African soldiers into 'special' units indicated the persistence of the 'politics of difference' in post-1961 Angola. Black Angolan troops were valued for their superior knowledge of the terrain, their fluency in local dialects, and their familiarity with local usages and traditions; but some 
units also displayed a ruthlessness that earned them a notorious reputation. ${ }^{23}$ We can distinguish four major categories of special unit. The first comprised those placed under PIDE's (Polícia Internacional de Defesa do Estado, the Portuguese political police) supervision, both in organizational and operational terms. Such was the case of the TE (Tropas Especiais,or pecial Troops) initially formed in Cabinda in 1966 with 1,200 defectors from UPA/FNLA (Frente Nacional de Libertação de Angola), headed by Alexandre Taty, former leader of FLEC (Frente de Libertação do Enclave de Cabinda), a secessionist group set up in 1963. Another example was the Flechas ('Arrows'), a special combat unit that deployed Bushmen (Khoisan) from the Cuando-Cubango region in southeastern Angola. The Tropas Especiais would be incorporated in the regular army in 1971, with their number dropping to around 800, while the Flechas remained under PIDE's aegis right until 1974, when they numbered 2,270.24

The second category comprised units that were created and developed by the military authorities from 1968, known as the Grupos Especiais (Special Groups). These units initially constituted captured guerrilla fighters who decided to turn themselves in, the ranks later augmented by locally recruited volunteers. Although service in the GE's was seen as regular military service, their discipline and organisation was based on 'native traditions.' 25 As Matos Gomes' observes, GE's evolved from a self-defence militia model to one of a force possessing a high degree of autonomy and operational mobility, benefiting from a commando type instruction. ${ }^{26}$ GE's soon became the most popular and widely disseminated model of African special forces utilised by the Portuguese. The philosophy that underpinned their creation was the desire to recruit units from within the region in which they would serve. Coelho estimates the fighting force of the GE's to have peaked at around 3,250 men, the majority stationed near regular army battalions in the north, east and south of Angola. ${ }^{27}$

The army also provided training and operational direction to a third category of special African troops - units composed of foreign elements who had sought refuge in Angola. There were two such groups. The first, and most substantial, were the so-called 'Katangese gendarmes' - who had served in Katanga's secessionist gendarmerie set up by Moïse Tshombe in $1963 .{ }^{28}$ After 
their final defeat in 1967, many of these fighters escaped into the Lundaspeaking areas of north-east Angola. ${ }^{29}$ Though their opposition to Mobuto's Zaire made the Katangese an asset to the Portuguese, they were most effectively deployed in the Eastern Military Zone as a well-trained unit to combat MPLA (Movimento Popular de Libertação de Angola) and UNITA (União Nacional para a Independência Total de Angola) guerrilla activity. However, the Katangese were keener to act against Kinshasa's authorities than against Angola's nationalists, and so had to be handled with care. The camps in which they were stationed, Gafaria, Chimbila, and Camissombo, were heavily policed by the Portuguese authorities.30 By 1974, the Katangese were estimated as a force of c. 2,400 fighting elements, organized in 16 companies, scattered in various parts of Angola's Eastern Military Zone, and highly regarded by the Portuguese for their sense of discipline and operational efficiency. For these qualities, they were known as Fiéis - the "faithful ones". ${ }^{1}$

A smaller foreign contingent was provided by a band of dissenters from Kenneth Kaunda's Zambia. PIDE had become aware of the existence of such disaffection in 1967, when Operation Colt was launched to attract into eastern Angola any Zambians who might be employed in destabilizing operations or in combat against MPLA and UNITA guerrillas. ${ }^{2}$ Hypothetically, their reward would be Portuguese support to the overthrow of Kaunda's regime, an objective also cherished by elements of South Africa's security forces.33 Stationed in the Cazomba Salient, they were organized in a company (Special Group 600), undertaking several missions in support of the local army battalion. Never totalling more than 120 elements, they also received a flattering codename: Leais (the "loyal ones"), and they too were trained by army officers and monitored by PIDE officials. 34

Lastly, the fourth category of African forces comprised the largest number of irregular forces - the local militias - whose formidable growth in the war's final years (estimated at 30,000 by 1974) was a direct consequence of the expansion of the resettlement programs fostered by the Portuguese. 35 These militias operated under two banners. One was the OPVDCA (Organização Provincial dos Voluntários de Defesa Civil), which acquired an increasingly 
multiracial profile in its membership, and was fundamentally committed to the security of the colony's economic infrastructure (businesses, roads, communications networks). The other were known as the Corpo Militar de Segunda Linha (second line military corps), whose main task was to defend the 'strategic hamlets' and villages that were the core of the aldeamento program, its units normally operating under the supervision of a Portuguese army officer. ${ }^{6}$ Organized in platoons, only a small percentage had access to proper firearms, the majority relying on spears, bows and arrows and other 'homemade' weapons. 37 There is little information available on the ethnic composition of these forces, but although there were some examples of local ethnic animosities being exploited in a 'divide and rule' strategy, ${ }^{8}$ there was no general policy designed on ethnic lines. 39 Army documents do reveal, however, that these units were considered "expendable", frequently being deployed for the interception and pursuit of enemy groups, coups de main and other 'risky' missions. 40

Portuguese propaganda and general news coverage depicted these African allies as dedicated opponents of communist inspired 'terrorists', and inspiring examples of Portugal's capacity to foster a sense of patriotic allegiance among the native populations of the Ultramar. ${ }^{41}$ In other words, they were placed at the centre of the multiracial 'integrationist' ideology that was the heart of Portugal's late colonial orthodoxy, most notoriously in Angola. There is nothing in the documentary record to indicate that the Portuguese ever developed a clear view as to how such African forces might fare at the point of colonial "exit", or that the considered what the fate of such protagonists might be should a nationalist government ever come to power. ${ }^{42}$

While official Portuguese policy never countenanced the possibility of giving up colonial rule, covert negotiations did in fact take place with Angola's nationalists. The most important of initiative was the attempt made in the final years of the Portuguese counter-insurgency war in Angola to co-opt UNITA's rebel leader, Jonas Savimbi. From 1966, UNITA had waged a somewhat ineffective campaign in the eastern districts of Lunda and Moxico. To counter this, Operação Madeira (Operation Timber) began in 1971 as a non-aggression 
pact between the local military authorities and UNITA's chief, mediated by local timber merchants and a priest. This gradually evolved into a more complex dialogue as each side explored what concessions they might exact from the other.43 At the peak of this collaboration, the Portuguese agreed to provide medical assistance to Savimbi and abstain from engaging UNITA in combat, while UNITA guerrillas declined to attack the Portuguese army, supplied intelligence on MPLA camps, and directed their combat activities against the units of the MPLA. When these negotiations were revealed in 8 July 1974, a few days after UNITA became the first independence movement to reach a ceasefire agreement with the Portuguese, Savimbi did all he could to deny that such exchanges had ever occurred. But in the following years an impressive body of evidence gradually emerged, seriously undermining the credibility of such denials. 44

The success in neutralizing UNITA, and the general stabilization of the security situation in the eastern regions of Angola after 1972, was a major achievement for the Portuguese counterinsurgency, some even seeing this as a 'military victory'.45 With their own internal divisions, a lack of significant external military support, and the aggressive counter-insurgency tactics pursued by the Portuguese, each of the three Angolan insurgent movements were on the defensive from 1972 onwards. According to official records, by 1973 Portugal had 65,592 troops stationed in Angola, of which 27,819 were locally recruited (42.4\%).46 This compared with a total insurgent force of something like 10,000 to 15,000 combatants - and even this estimate may be inflated.47 The Portuguese were certainly not loosing their war in Angola in 1974, and they appeared to have secured a reliable body of African allies through a consistent policy opportunistic incorporation and strategic deployment: as Pellisier has observed, 'no African units ever mutinied or defected throughout the course of the war'. 48

The economic performance of the Angolan colony, boosted by the oil, mining and agricultural sectors, was equally impressive by 1974, although little of this prosperity benefitted Angola's native population. But in the last years of the colonial era, public investment in infrastructure increased, and the state was 
finally able to provide a number of public services to the African population in areas like rural development, education, sanitation and medical care. Even if its legitimacy in the eyes of the non-white population could hardly be taken for granted, the colonial state in Angola seemed reasonably well entrenched, and for the first time not only in the coastal areas, but in the hinterland regions as well. 49

\section{The road to Alvor}

Any complacency that a vision of "colonial progress" may have invoked was shattered in the near bloodless overthrow of Caetano's regime in Lisbon on 25 April 1974. Some of the key-figures of the officer's movement that led this coup, the MFA, had clear views on how Portugal's colonial disengagement should proceed. The purpose of the members of the coordinating committee of the MFA was to reach cease-fires with the African guerrillas in Guinea, Angola and Mozambique, as quickly as possible and then negotiate the arrangements for a swift transfer of power to the armed nationalist movements, whom they regarded as the sole legitimate interlocutors in any independence agreement for the colonies. However, this strategy was disputed by General Spínola, the officer the MFA co-opted to head the National Salvation Junta immediately after the deposition of Marcelo Caetano. Spínola, a prestigious military commander with his own decolonization agenda, tried to put forward an alternative route - self-determination for the overseas provinces through plebiscites organized by the Portuguese authorities under UN supervision - to the one favoured by the MFA. But the political dynamic unleashed by the coup in Lisbon, the growing ascendancy acquired by the 'progressive' wing of the MFA (which included a significant number of NCO's, many of them highly politicized and connected to left-wing political parties in the metropolis), as well as other international and local factors, soon exposed the shortcomings of Spinola's approach, especially in those territories where local conditions gave the guerrillas the upper hand against a rapidly demotivated and dysfunctional Portuguese conscript army.50

Although he was therefore compelled to give way in Guinea-Bissau and Mozambique, until his dismissal from the Presidency in late September 1974, 
Spínola took various steps to preserve a measure of Portuguese influence in post-independence Angola. This included an elaborate independence plan, first set out on 9 August 1974, and diplomatic approaches to Mobutu - allegedly to secure his support for a broad anti-MPLA coalition, formed by the FNLA and UNITA along with other political parties, associations and pressure groups, many of whose leading figures had close ties to the colonial regime. These efforts would ultimately fail, but it soon became evident that the Estado Novo's collapse had broken the morale of a large number of Portuguese military units in Angola, both in the regular army and among the 'irregular' or special African forces. In early July 1974, an orderly demonstration by black junior officers, sergeants and soldiers of the colonial army in Luanda, in protest against the passivity of the security forces towards acts of violence against black Africans in some of the capital's musseques (shantytowns), gave a serious warning that discipline was under threat in the racially mixed units of the army. ${ }^{51}$ On 17 July 1974, Spínola's appointed Governor of Angola, General Silvério Marques, had to be recalled to Lisbon after he was accused of obstructing the MFA's program and refusing to purge the much hated PIDE.

Silvério Marques was replaced by Rosa Coutinho, a naval officer whom the white settlers soon nicknamed 'Red Admiral', on account of his bias toward the MPLA and the Soviets. During Coutinho's stint as head of Angola's Governing Junta (from July to December 1974) significant steps were taken to dismantle or 'emasculate' a number of key institutions of the former colonial apparatus, as well as to facilitate the infiltration of several public services (including civilian and military radio stations) and economic structures by MPLA activists or fellow-travellers. At the same time, a number of white extremist groups were suppressed. $5^{2}$

By the time Spínola stepped down from the Presidency, on 28 September 1974, Agostinho Neto's emissaries from the MPLA were already embedded in Luanda and seeking foreign military assistance in Cuba, the USSR and other Eastern bloc countries.53 The balance of power in Lisbon now tilted unequivocally in favour of those in the MFA who wished to secure Portugal's interests in Luanda - though it would certainly prove difficult proved difficult to 
secure formal guarantees aimed at protecting the interests of the settler community, as well as the safety of those Africans who had collaborated with the colonial state. The Alvor summit, of 10 to 15 January 1975, brought together the FNLA, UNITA, MPLA and the Portuguese government, to work out the details of Angola's transition to independence. The fate of the former 'loyalists', both in the army and in other areas of the colonial bureaucracy (not least the networks of PIDE informants), was on the agenda, with the Portuguese making efforts to impress upon the nationalists the need to avoid arbitrary acts of reprisal, and if necessary to bring to Portuguese courts those who might face criminal charges for their complicity with the colonial regime. The Angolan negotiators were also informed that the PIDE archives were likely to be repatriated to Portugal while the summit was taking place: the Portuguese delegation adamantly refused to make any documents available to the nationalists. 54

The condition of the African elements serving in the colonial army, as well as the various 'irregular forces', was also discussed. Among the permanent cadre of the Armed Forces, those few Africans entitled to a state pension (a modest contingent) were given preference, while the future subsistence of all others could not be guaranteed by Lisbon. The Portuguese were keen to persuade the nationalists to accept the idea of an 'amnesty' that would apply to all those who had belonged to "military and paramilitary organizations, upon the initiative of the colonial authority".55 A secret additional protocol to the Alvor agreement was established to define the amnesty, but this measure was in no sense considered as binding - the Portuguese fully realising they would have no influence over this once power was handed over. The minutes of the Alvor meetings also show that there was considerable interest in the immediate fate of those Africans who had served in self-defence militias and 'special forces'. Not surprisingly, the nationalists were also concerned with what might happen to the weapons and equipment of such forces. The nationalists viewed such units as potential recruits to their own armed wings - whether or not these forces eventually merged into a future national army, as was intended in the Alvor agreements. $5^{6}$ Squabbling over the fate of these forces had in fact begun months earlier, with emissaries from all three nationalist movements (FNLA, MPLA and UNITA) visiting the camps of the Katangese Fiéis in an effort to recruit them to 
their cause.57 This was indicative of the covert military planning that both the FNLA and the MPLA were engaged in long before the elections scheduled for October $1975.5^{8}$

The MPLA were to some extent successful in assimilating former colonial soldiers into their own cadres, and this was achieved the complicity of key elements of the local MFA. On the one hand, the MFA's attitude was justified by the need to ensure a minimal equilibrium between the armed wings of the three movements. At this stage, Neto's MPLA, still recovering from the factional disputes that had enfeebled its leadership since 1972, was perceived by their Portuguese sympathizers as particularly vulnerable in terms of its military capacity (5,500 to 8,00o elements, although a number of them recruited from Luanda's Poder Popular committees, against Holden Roberto's estimated 21,000 combatants, and Savimbi's 3,000 to 8,000 fighters).59 On the other hand, there was an unmistaken pro-MPLA bias that was common not only to the 'progressive' wing of the MFA, but also to large sectors of the then hegemonic Portuguese left. This is usually explained by a mixture of ideological affinities (the MPLA being recognized as the only trustworthy movement in terms of its formal non-racial stance and commitment to a 'modern' socialist ideal), ${ }^{60}$ and a sense that some of the Lisbon and Coimbra educated leaders of the MPLA would facilitate a post-imperial 'fraternal' relationship, especially when compared with the profiles of its two rival movements: Roberto, established in Kinshasa for more than 15 years, was seen by many as a 'pawn' of Mobutu; whereas Savimbi, educated in American protestant missions, was perceived as an opportunist all too ready to resort to a chauvinistic rhetoric whenever the circumstances required it.

This MFA bias, however, was to some extent counterbalanced by the attitude of the 'caretaker' High Commissioner, General Silva Cardoso, a 'moderate' air force officer who tried to assume some equidistance towards the three Angolan parties. Very soon, though, he found himself totally impotent to ensure the enforcement of some of the basic arrangements enshrined in the Alvor accord and prevent the violent expression of factional antagonisms. On the 11 March 1975, political events in Lisbon (the ultimate defeat of the Spinolist 
faction) paved the way for an intensification of the political in-fighting and further undermined the cohesiveness of the departing colonial power. The dispatch of special army units (paratroopers and commandos) to reinforce or replace contingents stationed in Angola could no longer be taken for granted, and the operational capacity of the remaining Portuguese army units was, in some places outside Luanda, next to nil.

It was against this backdrop that the enlistment of former colonial troops in the paramilitary units of the rival nationalist parties gathered pace. In this process, expediency overruled considerations of the suitability and reliability of the men to be recruited. Once more, the documentary evidence on this is scarce and fragmentary, although the Katangese Fiéis present an exception here. With the retreat of the Portuguese, the Katangese Fiéis were caught in a delicate situation. They especially feared the possibility that Holden Roberto's FNLA (highly dependent on Mobutu's support) might manage to seize power in an independent Angola. In the previous months, Portuguese officials hesitated as to the best solution for these foreign soldiers, but the consensus had been to avoid delivering them either to Mobutu, and perhaps negotiate their admission in one of the neighbouring 'white' states, be it Rhodesia or South Africa. ${ }^{61}$ Gradually, however, the prospect of an alliance with an MPLA started to assert itself. The fact that Major Pezarat Correia, a key MFA member in Angola, had been responsible for the supervision of all the 'irregular' units stationed in the east, seems to have been a critical factor in the rapprochement that was now reached between the MPLA and the Fiéis. In early 1975, their leader, General Nathaniel Mbumba, was persuaded by Coutinho to come to terms with the MPLA leadership, since the Mobutu/Neto antagonism would provide a sound basis for a fruitful cooperation. Having already 'rebranded' themselves the 'National Front to the Liberation of Congo' (FNLC in its French acronym) under the previous regime (in order to dissipate their reputation as a purely mercenary force), they were now also keen to choose a more fitting military label for themselves in 1975: they choose Tropas de Infantaria $e$ Guerrilha Revolucionária, the acronym of which was Tigres ("Tigers"). ${ }^{62}$ 
A more obscure case is that of the Zambian Leais, whose small numbers made the Portuguese less concerned as to their immediate future. At the Alvor summit they were referred to as either having escaped to South Africa, or returned to Zambia. In fact, some of them, the supporters of Adamson Mushala, a Zambian dissident politician who resorted to armed struggle in the early 1970s, had already received political asylum from South Africa, and were transported in a Portuguese military airplane to Caprivi, in November 1974. ${ }^{63}$ Those who preferred to stay in their camp in Calunda may have reached and accommodation with UNITA. Since Savimbi's movement was at the time backed by Lusaka, it is likely that some sort of amnesty may have been secured and used as an inducement to attract them to UNITA.

The scarce evidence we possess regarding other elements suggests that the assimilation of former 'loyalists' in the various para-military wings of the three movements rested on a number of factors. These may have included the regional location of their original units, family ties and ethnic affinities. ${ }^{64}$ Thus, significant members of the GEs, mainly drawn from the Bakongo people in the Angolan provinces bordering Zaire, appear to have joined the FNLA, allowing it to became the strongest force in the north - with the exception of Cabinda, where former $T E$ s soldiers ${ }^{65}$ helped to resurrect the local micro-nationalist group FLEC (apparently with the encouragement of a subsidiary of the French oil company Elf);66 while some former Flechas opted for the MPLA, the movement that had acquired great influence in the enclave immediately after Rosa Coutinho authorized a joint MPLA/MFA operation (October 1974) to depose a local governor, a Portuguese military officer, who was allegedly facilitating the separatist's organizing efforts. ${ }^{67}$ A number of ethnic Ovimbundu from the TEs appear to have accepted the compensations of the Alvor demobilization program and then headed south, to join UNITA forces. Stationed in bases located in the northern and eastern military zones, many of the c. 3000 GEs appear to have dissolved either in the ranks of the FNLA or the MPLA, but here ethnic allegiances may not have played such a decisive role.

Another factor that needs to be taken into account were the personal acquaintances or even the bonds forged between former colonial officers and their subordinates. This seems to have been an important element in the choices 
made by the aforementioned Fiéis and other special forces based in the east, but also by some of the Flechas in the Cuando-Cubango region, ${ }^{68}$ whose PIDE instructors were making their way to South Africa to join the motley groups of mercenaries and former Portuguese army officers that were about to take part in various Western sponsored interventions aimed at preventing a Soviet-Cuban victory in Angola.

Very little is known of the trajectories of the Africans who performed auxiliary roles in the rural militias in various districts, or in sundry security forces (PSP [Polícia de Segurança Pública, the urban police], Rural Guard, Fiscal Guard, DIAMANG's (abbreviation for the Diamond Company of Angola, a multinational concession company) private police), but various sources suggest a pattern of dispersion among the three movements similar to the one observed in the special forces, again with preferences dictated by the same set of motives. Their demobilization also implied the plundering of an arsenal of some 40,000 light weapons (and in some cases of radio equipment and files). 69

In the case of Luanda, however, it is likely that after the MPLA's victory for the control of the city (July 1975) those who may have hesitated regarding their future allegiances now had a powerful incentive to align their fortunes with Neto. While some Portuguese elite units, such as the paratroopers, may have retained a significant operational capacity, the fact is that a sense of disorientation and impotence became evident among the Portuguese authorities. The policy of 'active neutrality' proclaimed on 22 May 1974 by the Revolutionary Council in Lisbon (the supreme organ of the MFA, created after the 11 March events) was resented both by the MPLA (which expected a more forthcoming attitude from their leftist sympathizers in Lisbon), and by some high ranking Portuguese officers in Angola who felt disorientated towards such an 'ambiguous' concept.70 After declaring that the basic provisions of the Alvor agreements should be considered as 'suspended', and having failed all its attempts to reconcile the belligerents, Portugal's logical step, as the acting 'administrative power', should have been to postpone the independence date: but this was no longer a realistic option. 
Space constraints prevent us from elaborating on the complex factors that determined the outcome of the first instalment of the Angolan civil war, which culminated in the recapture of almost all the provinces held by the FNLA and UNITA by the MPLA forces in November and December 1975, and the wide international recognition of Neto's government (February-March 1976). The impact that some of the former loyalists may have had in a number of decisive confrontations, in a 'conventional' conflict that was new to many of them, is still largely undocumented. Nevertheless, a few accounts do mention the specific contribution made by some of them. This is the case of the 200 Katangese who took part in the Quifangondo battle (10 November 1975), which halted the advance of a column of FNLA soldiers, Zairians and Portuguese mercenaries that tried to launch an assault on Luanda before the Alvor's agreed independence date (11 November), as well as in other combats against UNITA forces in Lucusse and Luena, in the Moxico district. ${ }^{71}$ Some Bushmen from Flechas, together with soldiers loyal to Daniel Chipenda, a former MPLA guerrilla commander and Neto challenger who shortly after the Alvor agreement allied himself with the FNLA, are also credited to have participated in Operation Savannah as an autonomous company in South Africa's Defense Force (Combat Group Alpha, renamed 32 ['Buffalo'] Battalion in 1976).72

\section{Post-independence trajectories}

Given the fact that the new regime which emerged after the dissolution of the colonial order in Angola derived its legitimacy from the anti-imperialist stance taken by its founding party, it is not surprising that former loyalist combatants who eventually joined the ranks of their former enemies preferred to keep silent as to their past experience as collaborators of the Portuguese. Understandably, their new masters were also prone to embrace a pragmatic stance in order to take full advantage of their military skills and know-how.

Looking at some of the dimensions of the 'Africanisation' drive of the 1960s, a number of questions raised by Douglas Wheeler in an article published in 1976 remain difficult to answer73. For instance, what were the motives for the relatively large adhesions of Africans to Portugal's auxiliary/special troops? 
And what was the measure of coercion and free will in those enlistments? The aim for better living conditions, ensured by a regular salary, medical care and other benefits, such as schooling and agricultural assistance, as remarked by Cann, is a plausible explanation. Cann also mentions a situation common in many counterinsurgency scenarios, the 'allure' of the winning side, which in vast areas of Angola was more likely to be associated with the Portuguese, at least from 1972.74 One may also take into account the possibility that the enlistment of some Africans in the new forces set up during the counterinsurgency campaigns may have been determined by a tradition of military service in their own families, as it happened in many imperial contexts. The notion that the colonial authorities may have somehow been successful in fostering a sentimental allegiance to the 'multiracial' mythology of the Ultramar among large sectors of the African population, in part thanks to the multi-ethnic composition of the regular army units, 75 seems more difficult to sustain however. The political expectations of Angola's 'foreign' combatants, the Katangese and Zambians, was of course different. Here, Portugal's stance was typically cynical. Promises of support to an overthrow of the Mobutu and Kaunda regimes were made in order to sustain the motivation of these units, but Lisbon was all too aware of the powerful Western interests that were implicated in the survival of the governments in Kinshasa and Lusaka.

Although we know relatively little about the careers of the men who made the transition from ex-colonial troops to the armed forces of the new Angolan state, the FAPLA (Forças Armadas Populares de Libertação de Angola, rebranded as Forças Armadas Angolanas [FAA] after the 1991 peace accords), some were able to reach high positions, up to the rank of General. ${ }^{76}$ In the case of the MPLA regime, the dramatic absence of trained cadres and personnel able to operate the basic structures of the economy and state apparatus inherited from the colonial era (the oil sector and the armed forces being the most obvious examples), encouraged the ruling elite to adopt an attitude of expediency towards many individuals whose political backgrounds may otherwise have been considered suspect. Hence, the significance of 'situational' factors (to the detriment of other allegiances, ideological or ethno-political, for instance), as recently highlighted by several case studies of 'mobile' African 
soldiers in the context of the liberation struggles of Southern Africa, is confirmed by these Angolan examples 77 .

With regard to the most 'peculiar' contingent of the former allies of the Portuguese, the Katangese, pragmatism was also in evidence. In August 1978, in the aftermath of the two 'Shaba Wars', Mobutu and Neto, under significant pressure from their international patrons to reach a modus vivendi, agreed to cease support for groups committed to the overthrow of their respective regimes. Nevertheless, former FLNC (Front de Libération Nationale du Congo)members (or their descendants) were assimilated into FAPLA's ranks and, according to Larmer and other sources, continued to be employed in operations against UNITA in the following decades, 'particularly in the strategic diamond mining areas close to the Zairian border'78, as well as in support of Laurent Kabila against Mobutu in 1997.79

The easy assimilation of former loyalists in the post-1974 period in Angola by the armed wings of the three independence movements, and the absence of any massive or organized vengeance against them, presents a striking contrast with the fate of similar forces in Guinea-Bissau and Mozambique, not to mention the tragic destiny of many Algerian harkis in 1962.80 In GuineaBissau, a number of ex-African commandos and members of the local militias (on whom Spínola had relied both to improve his operational efficiency, as well as to promote his 'hearts and minds' campaign Por uma Guiné Melhor/For a Better Guinea) were arrested by the PAIGC's (Partido Africano para a Independência da Guiné e Cabo Verde) security forces. Some years later an unspecified number of those former loyalists ended up being executed: initially in 1975, and then again in 1980. In the first instance, the number of eliminated soldiers may have totalled $53^{81}$; in the aftermath ofthe coup that overthrew the government dominated by the PAIGC's Cape Verdean elite, the sole newspaper published in Guinea-Bissau, Nô Pintcha, published a list of 500 executed individuals, but many more are also believed to have been eliminated.82 A small number of former commandos and militias were able establish themselves in Portugal after Guinea's independence, where many struggle to survive with their state pensions and get proper medical assistance. Expressions of official recognition for their contribution to the war effort in Guinea were discreet and 
somewhat conditioned by the controversial status that the colonial wars still retain in Portugal's collective consciousness. But they have received support from several veterans' associations to seek an improvement of their living condition and better access to health care provisions. ${ }^{83}$

In independent Mozambique there was a kind of 'in-between' situation. FRELIMO (Frente de Libertação de Moçambique) emerged highly confident from the Lusaka agreement with Portugal (6 September 1974) and, for a number of reasons, was unwilling to integrate en masse former loyalist troops in the ranks of the newly constituted armed forces. Having ruled out the type of drastic solution adopted by the PAIGC, its leadership was nevertheless aware of the threats that a disbandment of such 'internal enemies' might pose to the state's security. Therefore, they chose a different path: the social and political 'rehabilitation' of the former colonial 'collaborators'. This was done through their interment in 're-education camps' and through the public diffusion of testimonies in which these 'new men', now devoted to the revolutionary cause, expressed their repentance. As Borges Coelho has shown, this process appears not to have achieved its main goals, since many of them ended up crossing the border to Rhodesia and form the embryo of RENAMO (Resistência Nacional Moçambicana), the anti-FRELIMO guerrilla movement that would wage a long attrition war against Maputo's government (with the assistance of Rhodesia and South Africa). 84

Determined to ensure a friendly and cooperative bilateral relationship with the new authorities of their former colonial territories, the political and military elite who ruled post-revolutionary Portugal lacked the means, and the interest, to act on behalf of many of these former loyalists. In the case of Guinea, efforts were indeed pursued by veterans' organizations to ensure that some of the legal provisions regarding Lisbon's obligations towards their former African soldiers were put into effect, but for many years the executions which took place in 1975 (and afterwards) went almost unnoticed in the Portuguese media. In the case of Angola such problems did not arise. But the immediate evolution of the relationship between Lisbon and Luanda was fraught with political misunderstandings and diplomatic incidents, which can in many cases be traced 
to the transition period. In 1974-75, the Portuguese state was itself experiencing a convoluted process in which different factions struggled to assert their supremacy, something that made the pursuit of a coherent policy towards Angola extremely hard. The MPLA leadership resented the 'reluctant' attitude which the left and centrist parties in Portugal had adopted vis-à-vis the recognition of Neto's regime in late 1975, and this soured the Luso-Angolan relationship for years to come. Eventually, it was the links which former MFA officials had been able to forge with senior MPLA figures that would allow for a measure of normalization' in the late 1970s, symbolized by Ramalho Eanes and Agostinho Neto's Bissau summit in 1978, something which, ironically, several centre-right Portuguese governments, ideologically at odds with the MPLA's Marxist stance, were keen to capitalize in the following decades. ${ }^{85}$

\section{Endnotes}

${ }^{1}$ On Caetano's colonial predicament, see, amongst others, P. A. Oliveira, 'Uma Mão Cheia de Nada? A política externa do marcelismo', Penélope, xxvi (2002), 93-122; and V. P. Valente, Marcelo Caetano - As Desventuras da Razão (Lisboa, 2002).

${ }^{2}$ See N. MacQueen 'As guerras coloniais', in F. Rosas and P. A. Oliveira (eds.), $A$ Transição Falhada. O Marcelismo e o Fim do Estado Novo 1968-1974 (Lisboa, 2004), 265-300; and G. Bender, Angola and the Portuguese. The Myth and the Reality (Trenton NJ, 2004, $2^{\text {nd }}$ ed.).

3 For this historical background, see the articles by D. L. Wheeler, 'The Portuguese Army in Angola', Journal of Modern African Studies, vii (1969), 425-439 and 'African elements in Portugal's Armies in Africa (1961-1974)', Armed Forces and Society, ii (1976), 233-250; J. P. Cann, Counterinsurgency in Africa. The Portuguese Way of War 1961-1974 (Westport CT, 1997), 87-110; and J. P. B. Coelho, 'African Troops in the Portuguese Colonial Army, 19611974: Angola, Guinea-Bissau and Mozambique', Portuguese Studies Review, x (2002), 129-150.

4 Coelho, 'African Troops', 131.

5 P. P. Correia, 'A participação local no desenvolvimento das campanhas' in Instituto de Altos Estudos Militares, Estudos Sobre as Campanhas de África 1961-1974 (Estoril, 2000), 144.

${ }^{6}$ D. L.Wheeler and R. Pélissier, Angola (London, 1971), 96. 
7 See J. Dias, 'Uma questão de identidade. Respostas intelectuais às transforamações económicas no seio da elite crioula da Angola portuguesa entre 1870 e 1930', Revista Internacional de Estudos Africanos, i (1984), 61-93.

${ }^{8}$ F. da C. Rodrigues, Antigos Combatentes das Forças Armadas Portuguesas. A Guerra Colonial como Território de (Re)Conciliação (Coimbra: Unpublished PhD thesis, 2012), 117-118.

9 Coelho, 'African Troops', 133. R. Pélissier, La Colonie du Minotaure. Nationalismes et Revoltes en Angola 1926-1961 (Orgeval, 1978), 318, observes that such practices were still common in the Congo district of Angola in the mid1950s.

10 Rodrigues, 'Antigos Combatentes', 120-121.

${ }^{11}$ Ibid., 123-124.

12 See, e.g., A. Monteiro, Para Uma Política Imperial (Lisboa, 1934), 107.

13 Coelho, 'African Troops', 114.

14 Cann, Counterinsurgency in Africa, 6.

15 Rodrigues, ‘Antigos Combatentes’.

16 Coelho, 'African Troops'.

17 Cann, Counterinsurgency in Africa, 88.

18 On the consequences of this explosion of violence, see Wheeler and Pélissier, Angola, 173-225; and Pélissier, Colonie du Minotaure, 301-664.

19 See Cann, Counterinsurgency in Africa, 88-91.

20 Figures taken from Correia, 'A participação local', 154.

${ }^{21}$ According to the 1960 census, Angola had a population of 4,830,449, of which $172,529(3,6 \%)$ were whites; in 1970 the province's population totaled $5,673,046$, of which $290,000(5,1 \%)$ were whites. Figures taken from F. T. Pimenta, 'Angola's Euro-African Nationalism. The United Angolan Front', in E. Morier-Genoud (ed.), Sure Road? Nationalisms in Angola, Guinea-Bissau and Mozambique (Leiden, 2012), 197.

22 See Pélissier, Colonie du Minotaure, 317. To become an officer one had to possess at least a complete secondary education, a situation that remained uncommon among the black population of Angola well into the early 1970s. Mestiços (some of them of Cape-Verdean origin), however, seemed to have fared better in this respect. 
23 For an overview of these forces, see Cann, Counterinsurgency in Africa, 95103, and his article 'The artful use of national power: Portuguese Angola (19611974)', Small Wars and Insurgencies, xxii (2011) 196-225; Coelho, 'African Troops', and C. M. Gomes, 'A Africanização na Guerra Colonial e as suas sequelas. Tropas locais - os vilões nos ventos da história', in M. P. Meneses and B. S. Martins (eds.), As Guerras de Libertação e os Sonhos Coloniais (Coimbra, 2013), 123-141. See also episode 15 from the $2^{\text {nd }}$ season of the TV documentary $A$ Guerra ("The War"), by Joaquim Furtado, aired by RTP (Portuguese public broadcast) in 2009 (accessible on DVD).

24 On the history of the Flechas, see J. P. Cann, The Flechas: Insurgent Hunting in Eastern Angola, 1965-1977 (Solihull [UK], 2013); Coelho, 'African Troops', 146

25 On their statutory rules, see Arquivo Histórico Militar (hereafter AHM), Lisbon, Portugal, "Directiva No 14/71/TI - Grupos Especiais”, 25 August 1971, DIV 2/2/139/4.

26 Gomes, 'A Africanização', 129.

27 Coelho, 'African Troops', 146.

${ }^{28}$ See M. Larmer, 'Of Local Identities and Transnational Conflict: the Katangese Gendarmes and Central-Southern Africa's Forty Years War, 1960-99', in N. Arielli and B. Collins (eds.), Transnational Soldiers. Foreign Military Enlistment in the Modern Era (Basingstoke, 2013), 160-178.

29 Actually, a sizable number of Katangese gendarmes (up to 3,000 according to PIDE documents) had sought refuge in Angola as early as 1963, following the first defeat of Tschombe's secessionist movement. They were initially treated as 'refugees' by the Portuguese authorities, but their sojourn was somewhat troublesome. They were repatriated to the Congo in September 1964, after Tshombe's brief stint in Leopoldville as prime-minister: Arquivos Nacionais Torre do Tombo [hereafter ANTT] /PIDE/DGS (Lisbon, Portugal), Del A, Luanda, No Proc. 50, UI 8978; Larmer, 'Of Local Identities', 167-168.

30 See for instance the report from Captain Dionísio Almeida Santos: AHM, Inspecção aos campos dos Fiéis, 1 August 1972, DIV 2/2/139/16.

${ }^{31}$ See the appreciations contained in the report on their operational activities for the years 1971-72 by the Cabinet of the Auxiliary Forces of the GeneralHeadquarters of the Portuguese Armed Forces in Angola: AHM, Comando Chefe das F.A. em Angola, DIV 2/2/139/4.

${ }^{2}$ See Cann, 'The artful use'.

33 See M. Larmer, Rethinking African Politics. A History of Opposition in Zambia (Farnham, 2011), 142-3.

34 Coelho, 'African Troops', and Cann, 'The artful use'. 
35 Cann, Counterinsurgency in Africa, 160.

${ }^{6}$ Ibid, 160-1.

37 G. Bender, 'The limits of counterinsurgency: an African case', Comparative Politics, iv (April 1972), 336.

38 Cann, The Flechas, 27-30.

39 See the general remarks by M. Cahen, 'Luta de emancipação anti-colonial ou movimento de libertação nacional? Processo histórico e discurso ideológico - o caso das colónias portuguesas e de Moçambique em particular', Africana Studia, viii (2005), 52-6.

40 References to their 'primitive methods', or to 'idiosyncratic' notions of discipline deriving from a 'peculiar mentality', appear in several army documents. See, e.g., AHM, 'Proposta para utilização de refugiados catangueses - Muito Secreto' (197?), DIV 2/2/139/13 - Utilização de Refugiados Catangueses.

${ }^{41}$ See the press clippings of several Angolan newspapers (1967-70) related to Flecha's activities in ANTT/ PIDE/DGS, Fundo SC, UI 7944, UI 7945 and UI 7946. The articles use expressions such as 'aggressiveness', 'sang-froid', 'total disregard for their own life', 'sense of mission', 'moral and physical courage', to pay tribute to several decorated Flechas.

${ }^{42}$ For the notion of 'exit strategy' in a colonial context, see Richard Caplan (ed), Exit Strategies and State Building (Oxford, 2012), especially the chapters by Darwin, Chaffer, and Spruyt.

43 See the documents edited and introduced by W. Minter, Operation Timber: pages from the Savimbi dossier (Trenton NJ, 1988).

44 On Savimbi see the sympathetic, but nevertheless useful, biography by $\mathrm{F}$. Bridgland, Jonas Savimbi: a key to Africa (New York, 1987).

45 Cann, Counterinsurgency in Africa, 163, and A. P. Nunes, Angola 1966-74Vitória Militar no Leste (Lisbon, 2002).

46 Coelho, 'African Troops', 136.

47 S. Weigert, Angola: a Modern Military History 1961-2002 (New York, 2011), 51.

48 Ibid. As Pélissier, Colonie du Minotaure, 322, remarks, even though subtler forms of discrimination persisted after 1961, participation in the Portuguese army remained 'a source of prestige, promotion and protection for the African soldier'. 
49 See R. S. de Oliveira, "O Governo está aqui": post-war state-making in the Angolan periphery', Politique Africaine, cxxx (2011), 165-187.

50 On the MFA genesis and later development, see D. Porch, The Portuguese Armed Forces and the Revolution (London, 1977). For its specific role in the decolonization process, see K. Maxwell, 'Portugal and Africa: the last empire' in P. Gifford and Wm. R. Louis (ed.), The Transfer of Power in Africa: Decolonization, 1940-196o (New Haven, 1982), 337-385; and N. MacQueen, The Decolonization of Portuguese Africa: Metropolitan Revolution and the Dissolution of Empire (London, 1997).

${ }^{51}$ On the links between this demonstration and the pro-MPLA groups in Luanda, see the memoirs of the MPLA activist, and later minister and ambassador, M. P. Pacavira, Memórias 1974/76. Angola e o Movimento Revolucionário dos Capitães de Abril em Portugal (Odivelas, 2011, 2nd ed.), 1921.

52 Pacavira, Memórias, 27-35.

53 On the MPLA's efforts to amass external assistance, see P. Gleijeses, Conflicting Missions. Havana, Washington and Africa 1959-1976 (Chapel Hill, 2002), 242-250; and O. A. Westad, The Global Cold War. Third World Interventions and the Making of Our Times (Cambridge, 2008), 218-240.

54 See the Alvor minutes for 14 and 15 January in AHM. FO 43/6/843/44 CCPA. Processo de Descolonização de Angola, Janeiro 1975. Acordos de Alvor. See also the synthesis provided by A. Marques, Segredos da Descolonização de Angola (Lisboa, 2013), based on a set of minutes held by the 25 April Documentation Center (Coimbra), more complete than the one deposited in the AHM.

55 Marques, Segredos, 209.

56 Ibid., 169-211.

57 AHM, FO 43/1/839/28 - Catangueses: Report from the Mission to the Zairian Refugees (ex-Fiéis) sent by the High Commissioner [Silva Cardoso], 4 April 1975.

58 See Tali, O MPLA perante si próprio, vol. 2, 49.

59 Weigert, Angola, 57. These figures, most likely based on the propaganda claims of the three Angolan movements, should be treated with caution.

6o Maxwell, 'Portugal and Africa', 363-4.

61 AHM, FO 43/4/840/31 - CCPA: Processo de Descolonização de Angola, Abril 1974 [na verdade Outubro de 1974]-Julho 1975. Actas da Comissão Nacional de Descolonização. See minutes of the 28 November 1974 session, in which the future of the 'Katangese gendarmes' was extensively debated. 
62 Larmer, 'Of Local Identities’, 171.

63 Larmer, Rethinking African Politics, 145.

64 M. Rupiya and A. Leão, 'A military history of the Angolan Armed Forces - as told by former combatants', in M. Rupiya (ed.) Evolutions and revolutions: A contemporary history of militaries in Southern Africa (Pretoria, 2007), 16; and W. Minter, Apartheid's Contras. An inquiry into the roots of war in Angola and Mozambique (London, 1994), 177.

65 According to Coelho, at the time approximately 400 TEs were stationed in Cabinda and 300 in the northern districts of Zaire and Uíge: J. P. B. Coelho, 'Da violência colonial ordenada à ordem pós-colonial violenta', Lusotopie (2003), 191.

66 Gleijeses, Conflicting Missions, 262.

67 MacQueen, The Decolonization, 173.

68 Coelho, 'Da violência', 18, offers an estimate of 2375 men, organized in 45 combat groups, predominantly based in the south. Portuguese authorities estimated that 3/4 would join UNITA, 1/4 the MPLA, and a residual contingent would be assimilated by the FNLA.

69 Marques, Segredos.

70 M. I. Rezola, Melo Antunes. Uma biografia politica (Lisbon, 2012), 395-6.

71 See E. George, The Cuban Intervention in Angola 1965-1991. From Che Guevara to Cuito Canaval (London, 2005), 74, and M. Larmer, 'Local conflicts in a transnational war: the Katangese gendarmes and the Shaba wars of 197778', Cold War History, xiii (2013), 93. Curiously, the Katangese participation in the Quifangondo battle is not acknowledged by General M. Júnior's monograph on the FAPLA's history, Forças Armadas Populares de Libertação de Angola. $1^{\circ}$ Exército Nacional 1975-1992 (Lisboa, 2007).

72 Cann, The Flechas, 61, and J. Breytenbach, The Buffalo Soldiers. The Story of South Africa's 32 Battalion, 1975-1993 (Alberton, 2002).

73 Wheeler, 'African elements in Portugal's Armies in Africa (1961-1974)'.

74 Cann, Counterinsurgency in Africa, 103-4.

75 Ibid., 104.

76 Such is the case of General Luís Faceira, Angolan chief of staff in the early 1990s, whose brother, General António (Defunto) Faceira, commander of the FAA's special troops, had been a former MPLA guerrilla fighter. For this and further exemples, see J. N. Pinto, Jogos Africanos (Lisboa, 2008). 
77 See L. White and M. Larmer, 'Introduction: Mobilie soldiers and the UnNational Liberation of Southern Africa', Journal of Southern African Studies, $\mathrm{xl}, 6$ (2014), 1271-1274, as well as the article in that same special issue by V. Amukwaya Shigwedha, 'The relationship between UNITA and SWAPO: allies and adversaries', Journal of Southern African Studies, xl, 6 (2014), 1275-1287.

78 M. Larmer, 'Local conflicts', 173. Mobutu and Neto's 1978 agreement also allowed for the integration of a significant numbers of ENLA's (FNLA's armed wing) members in Angola's armed forces.

79 See J. N. Pinto, Jogos, 429-430.

80 On the harkis case, see M. Evans, 'The harkis: the experience and memory of France's Muslim auxiliaries', in M. S. Alexander, M. Evans and J. F. V. Keiger (eds.), The Algerian War and the French Army 1954-1962. Experiences, Images, Testimonies (Basingstoke, 2007), 117-133.

${ }^{81}$ See António Duarte Silva, 'Guiné-Bissau: libertação total e reconhecimentos portugueses', in F. Rosas, M. Machaqueiro and P. A. Oliveira (eds.), O Adeus ao Império - 40 Anos de Descolonização Portuguesa (Lisboa, 2015), 120.

82 See E. Dâmaso and A. Gomes, "Falecidos por Fuzilamento”, Público, 30 June 1995, and M. A. Bernardo, Guerra, Paz e Fuzilamento dos Guerreiros. Guiné 1970-1980 (Lisboa, 2007).

83 Rodrigues, Antigos Combatentes, chap. 5 and 6.

84 Coelho, 'Da violência', 190-191.

85 See N. MacQueen, 'Portugal and Africa: the politics of re-engagement', Journal of Modern African Studies, xxii (1985), 31-51 and 'Re-defining the 'African vocation': Portugal's post-colonial identity crisis', Journal of Contemporary European Studies, xi (2003), 181-199. 